\section{Effect of Hydrolysed Glucose Cycloacetoacetate in the Prevention of Fatty Infiltration in the Liver}

GLucose cycloacetoacetate (GCA) while hydrolysed with dilute hydrochloric acid has been found to have beneficial effects in experimental diabetes ${ }^{1-3}$. It has also recently been observed in this laboratory to facilitate transmethylation reactions in $E$. coli ${ }^{4}$. It was reported earlier by Saikia, Brahmankar and Nath ${ }^{5}$ that hydrolysed glucose cycloacetoacetate in a diaily dose of $80 \mathrm{mg} / 100 \mathrm{~g}$ body-wt can cause considerable desaturation of the liver fat, which, according to Sehoenheimer and Rittenberg ${ }^{6}$, is an indication of increased fat metabolism. Nath and Saikia ${ }^{7,8}$ have also observed earlier the prevention of atherosclerotic and hyperlipaemic conditions in animals by the hydrolysed product of glucose cycloacetoacetate (GCAH). Investigations were therefore undertaken to obsorve the lipotropic effect of GCAH in experimental animals. Because vitamin $B_{12}$ is known to have a lipotropic effect it was also thought desirable to study the effect of very small doses of vitamin $B_{12}$ in partially hepatectomized animals.

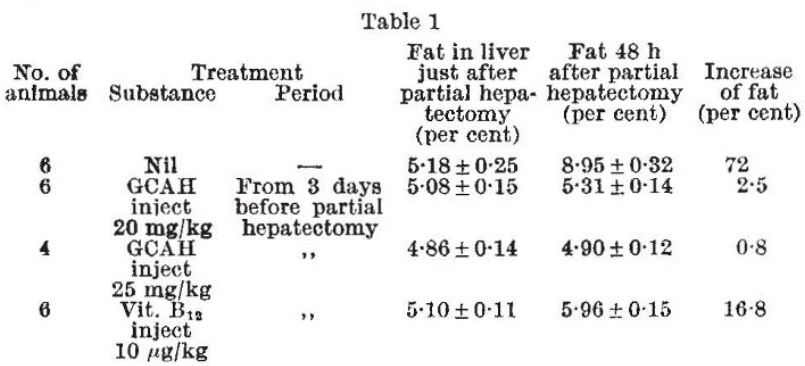

Montini and Pontremoli ${ }^{9}$ have reported that, $48 \mathrm{~h}$ after partial hepatectomy of the rat, the remaining portion of the liver undergoes fatty degeneration with a very large increase in the percentage of fat. This technique was used in this investigation and the experiment was made with twenty-two rats each weighing about $200 \mathrm{~g}$. Sixteen animals were used for the experiment and six as control. GCAH and vitamin $\mathbf{B}_{12}$ were injected intraperitoneally for three consecutive days before partial hepatectomy and for 2 days more thereafter before killing. The results are shown in Table 1.

It is thus evident from the results that GCAH, which has been found to help formation of methionine ${ }^{10}$ as well as choline ${ }^{11}$ in liver, is also lipotropic in nature.

Further investigations are in progress.

N. NATH

V. D. YAWALKAR

Department of Biochemistry,

M. C. NATH

University of Nagpur, India.

1 Nath, M. C., and Bhattathiry, E. P. M., Metabolism, 5, 11 (1956).

${ }^{2}$ Nath, M. C., and Behki, R. M., Metabolism, 6, 127 (1957).

3 Nath, M. C., and Behki, R. M., Arch. Biochem. Biophys., 75, 65 (1958).

- Nath, M. C., and Nath, N. (paper communicated).

- Saikia, A. Brahmankar, D. M., and Nath, M. C., Ann. Biochem. and Exp. Med., 19, 275 (1959).

' Schoenheimer, R., and Rittenberg, D., J. Biol. Chem., 113, 505 (1936).

'Nath, M. C., and Saikia, A., Ind. J. Physiol. and All. Sci., 13, 102 (1959).

8 Nath, M. C., and Saikia, A., Arch. Biochem. Biophys., 84. 162 (1959).

- Montini, T., and Pontremoli, S., Boll. Soc. Ital. Biol. Sper., 26, 8 (1950).

${ }^{10}$ Nath, M. C., and Saikia, A., Arch. Biochem. and Biophys., 79, 216 (1959).

11 Brahmanker, D. M., and Nath, M. C., Ann. Biochem. and Exp. Med., 23, 65 (1963).

\section{Rapid Method for Selenium Assay of Plant Material}

We have found the following to be a particularly rapid and reproducible means of assaying for selenium in leafy plant material. It is based on the use of perchloric acid and $\mathrm{H}_{2} \mathrm{O}_{2}$ to facilitate digestion and clarification of the sample and on the spectrophotometric determination of the elemental seienium produced on reduction of the combined forms of the element. Our method represents, in part, a combination of techniques recently found useful for higher plant and microbial material ${ }^{1-3}$.

We used the selenium-accumulator Astragalus bisulcatus I. in soil watered once daily with 1 p.p.m. of selenium as $\mathrm{Na}_{2} \mathrm{SeO}_{3} \cdot 5 \mathrm{H}_{2} \mathrm{O}$ and the closely related non-accumulators $A$. canadensis $\mathrm{L}$. and $A$. succulentus $\mathrm{L}$., grown in the same way except that no selenium was added to the soil in which the latter species were grown.

Approximately $0.5 \mathrm{~g}$ fresh weight of the plant sample containing $\mathrm{Se}$ is ylaced in a $250-\mathrm{ml}$. Erlenmeyer flask, to which is added $10 \mathrm{ml}$. of the digesting mixture consisting of 3 parts cons. $\mathrm{HNO}_{3}$ and 1 part of $\mathrm{HClO}_{4}$ ( 60 per cent). The mixture is heated gently on a hotplate until all the $\mathrm{HNO}_{3}$ is driven off and the fumes of $\mathrm{HClO}_{4}$ begin to fill the flask. After the material is completely digested, the flask is cooled thoroughly in cold water. $2-3 \mathrm{ml} . \mathrm{H}_{2} \mathrm{O}_{2}$ is added, and aftor 5 min or more the flask is reheated until fumes of $\mathrm{HClO}_{4}$ appear again, and all the $\mathrm{H}_{2} \mathrm{O}_{2}$ has been expelled. The clear and colourless sample is again cooled and the flask is then placed into a boiling-water bath for $2-3 \mathrm{~min}$. A mixture of $10 \mathrm{ml}$. of a 3 per cent hydrazine sulphate solution plus $3 \mathrm{ml}$. of a 2.5 per cent solution of gum arabic is added. It is extremely important to add the mixture in aliquots of $2 \mathrm{ml}$. or less and to allow a short period of time between addition. The flask is then placed in the boiling-water bath for $10 \mathrm{~min}$, by which time the characteristic orange-red colour of elemental Se should be fully developed. The suspension is transferred to a volumetric flask and made up to $25 \mathrm{ml}$. with distilled-water. The absorbancy of the samples at $420 \mu$ is measured in a spectrophotometer (Beckman $D U$ ) and the Se concentration is calculated using the straight-line calibration curve obtained from known concentrations of elemental Se. To prepare the standards, $1.0 \mathrm{~g}$ elemental Se is added to $10 \mathrm{ml}$. eoncentrated $\mathrm{HNO}_{3}$ and the mixture heated to dryness on a hotplate. $10 \mathrm{ml}$. distilled water is added, and the suspension is again dried by heating. The addition of water and heating is repeated twice. The Se is now treated as in the preparation of the unknown sample, except that the $\mathrm{H}_{2} \mathrm{O}_{2}$ can be omitted, as has been shown by preliminary tosts. The final dilutions can be varied according to the expected range of $\mathrm{Se}$ concentrations in the unknown samples. The Se concentration of $A$. bisulcatus L. averaged 1,100 p.p.m., while the non-accumulators averaged 0.03 p.p.m., all on a fresh-weight basis.

This work was supported by U.S. Public Health Service grant A100596-C. We thank L. Sonstelie for technical assistance, and Dr. O. A. Beath of the University of Wyoming for seed of the Astragalus species.

\section{R. DUFF}

M. Chessin

Department of Botany,

Montana State University,

Missoula, Montana.

${ }^{1}$ Cousins, F. B., Austral. J. Exp. Biol. and Med. Sci., 38, 11 (1960).

' Falcone, G.. and Nickerson, W. J., Giorn. Microbiol., 8, 129 (1960).

${ }^{3}$ Watkins, J. H., Anal. Chem., 32, 981 (1960).

\section{Disruption of Protozoa by Indole and Related Compounds}

THE disruption of protozoa in saturated aqueous indole solutions, first described by Eadie and Oxford ${ }^{1}$, has been used in the preparation of enzyme extracts from rumen protozoa $^{2}$ and ribosomes from Tetrahymena ${ }^{3}$. This type of biochemical disruption is of interest not only because of its spectacular nature but also because it is selective for rumen protozoa and any associated bacteria are not broken ${ }^{2}$. In examining the disruptive effect of other compounds Eadie and Oxford ${ }^{1}$ confined themselves largely to those closely related to indole and skatole (see Table 1). They concluded that, while a fairly close relationship to the tryptophan structure might be important, the 